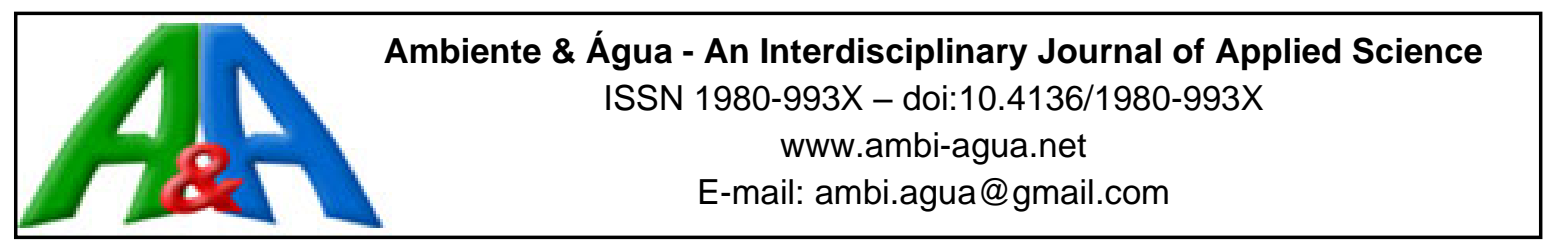

\title{
Evaluation of ecotoxicity of contaminated water for validation of phytoremediation time
}

\author{
ARTICLES doi:10.4136/ambi-agua.2393
}

Received: 14 Mar. 2019; Accepted: 09 Jan. 2020

\begin{abstract}
Katiúcia Dias Fernandes $^{1 *(\mathbb{D})}$; Amanda de Campos Roque ${ }^{1}$; ; Ana Lúcia Fonseca1(D)
${ }^{1}$ Instituto de Recursos Naturais (IRN). Universidade Federal de Itajubá (UNIFEI), Avenida BPS, n¹303, Caixa Postal 50, CEP: 37500-903, Itajubá, MG, Brazil. E-mail: amandacroque@yahoo.com.br, afonseca@unifei.edu.br *Corresponding author. E-mail: katiuciadf@gmail.com
\end{abstract}

\begin{abstract}
Phytoremediation has been used as an alternative for removal of heavy metals in aquatic environments, but plant residence time and toxicity reduction need to be studied. Ecotoxicological bioassays and root anatomic studies were conducted in order to validate the phytoremediation of Echinochloa crus-galli L. at three different ages. The experiment was conducted using E. crus-galli seeds with processing factorial experimental design $(2 \times 3)$ and four replicates. Cadmium presence and absence $\left(0.8\right.$ and $\left.0 \mathrm{mg} \mathrm{L}^{-1}\right)$ at three times $(20,30$, and 45 days after germination). Cd levels were quantified by flame atomic absorption spectroscopy on both aerial parts and roots. A bioassay was performed testing both acute and chronic effects using microcrustacean Daphnia similis with the purpose of evaluating phytoremediation efficiency. Regardless of biomass, E. crus-galli L. can be used for 16 to 19 days for 45 days after germination (DAG), tolerating the phytotoxicity of this metal. The residual solution after phytoremediation had chronic effect on $D$. similis, indicating that the time taken was not sufficient to reduce the toxicity of the solution. Thus, ecotoxicological essays are important tools in evaluating the efficiency of this type of process. While E. crus-galli L. is a valuable tool in $\mathrm{Cd}$ phytoremediation programs, exposure time must be higher than 19 days to reduce concentrations of this metal in the water to conform to the CONAMA 357/2005 e 430/2011 standards.
\end{abstract}

Keywords: acute and chronic effect, Echinochloa crusgalli L. macrophytes, time of exposure.

\section{Avaliação da ecotoxicidade da água contaminada com cádmio para validação do tempo de fitorremediação}

\section{RESUMO}

A fitorremediação tem sido utilizada como uma alternativa para remoção de metais pesados em ambientes aquáticos porém o tempo de permanência das plantas e redução da toxicidade precisam ser estudados. Neste sentido, bioensaios ecotoxicológicos e estudos da anatomia radicular foram realizados com o objetivo de validar a fitorremediação de Echinochloa crusgalli L. em três tempos após período de germinação. O experimento foi conduzido utilizando sementes de E. crusgalli L. com esquema fatorial $(2 \times 3)$ e quatro repetições. Presença e ausência de cádmio $\left(0,8\right.$ e $\left.0 \mathrm{mg} \mathrm{L}^{-1}\right)$ em três idades $(20,30$ e 45 dias após a germinação). Os níveis de $\mathrm{Cd}$ foram quantificados por espectroscopia de absorção atômica com chama nas partes aéreas e raízes das plantas. Bioensaios para avaliar os efeitos agudos e 
crônicos frente ao microcrustáceo Daphnia similis foi utilizado com intuito de avaliar a eficiência do processo de fitorremediação. Independentemente da biomassa, E. crusgalli L. até 45 dias após germinação (DAG) pode ser usado por 16 a 19 dias para remediação tolerando a fitotoxicidade deste metal. A solução residual após a fitorremediação teve efeito crônico sobre D. similis indicando que o tempo utilizando não foi suficiente para reduzir o efeito tóxico da solução. Conclui-se que os ensaios ecotoxicológicos são ferramentas importantes na avaliação da eficiência deste tipo de processo. Assim, E. crusgalli L. pode ser usado em programas de fitorremediação de $\mathrm{Cd}$ em baixas concentrações, porém o tempo de exposição deverá ser maior que 19 dias visando reduzir as concentrações deste metal na água de forma a atender os padrões CONAMA 357/2005 e 430/2011.

Palavras-chave: Echinochloa crusgalli L. macrófitas, efeito crônico e agudo, tempo de exposição.

\section{INTRODUCTION}

The removal of heavy metals from aquatic ecosystems has attracted attention, all around the world because of their pronounced or drastic effects as biosphere contaminants (Ullah et al., 2015). Among heavy metals, cadmium (Cd) is widely found in phosphates and zinc mining. It is also commonly used in rechargeable batteries (Ko et al., 2012) and eventually can reach aquatic bodies. Inhalation by occupational exposure has been historically registered, but the carcinogenic risk of cadmium-contaminated food and water have been ignored by regulatory agencies. The negative impact of $\mathrm{Cd}$ comes not only from its toxic effect but also from different accumulative capacities in different aquatic organisms (Ullah et al., 2015). In this context, Qiu and Wang (2016) observed in Daya Bay, a typical subtropical bay in southern China, that higher cadmium concentrations $\left(5.11 \mu \mathrm{g} . \mathrm{g}^{-1} \mathrm{dw}\right.$ ) were found in mollusks (Veremolpa scabra) than in shrimp and crab. In addition, according to these authors, higher $\mathrm{Cu}, \mathrm{Zn}$ and $\mathrm{Cd}$ concentrations have been recorded in wild fish than in animals kept in tanks. For example, Ekweozor et al. (2017) and Shovon et al. (2017) found heavy metals, including Cd in fish tissues above the limits allowed for human consumption according to FAO/WHO, which implies problems for human health. Remediation solutions, such as phytoremediation, need to be evaluated. Fawzy et al. (2012) indicate that plants might accumulate $\mathrm{Cd}$ in all tissues. In contrast to chemical analyses that identify and quantify the concentrations of toxic substances, the bioassays toxicity test evaluates the effect of substances on the organisms (Costa et al., 2008).

In the exhaustive search for alternatives to clean-up aquatic environments polluted with cadmium, two major requirements stand out, the simplicity of method efficiency and lower costs (Sharma and Pandey, 2014). According to De Souza and Silva (2019), the phytoremediation process is an excellent biotechnological technique in terms of expense and sustainability, since it aims at improvements with minimum impact to nature. Knowledge of the ideal plant age for higher absorption/accumulation in relation to the period of exposure is a key aspect for better implementation and usage of this technique. Gomes (2012) and De Souza and Silva (2019) emphasize that longer periods of exposure to contaminants are a negative point of this process; however, information about exposure time is largely unknown. Like any other remediation process, the use of plants is designed to reduce contaminant levels to levels that are safe and compatible with human health (Andrade et al., 2007). Singha et al., (2019) elucidate the importance of aquatic macrophytes in facilitating phytoremediation for global sustainability and environmental pollution. Aquatic macrophytes have been used in phytoremediation programs with metals in tropical regions. Their use has shown high rates of heavy metal removal of $85 \%-95 \%$ for iron, copper, zinc, cadmium, arsenic and chrome with plants of tested species such as Eichhornia crassipes, Pistia stratiotes, Lemna minor, Echinochloa crusgalli, among other macrophytes (Pereira et al., 2011; Martelo and Lara Borrero, 2012; Silva et al., 2013). Peng et al. (2017) cite that E. crusgalli has potential for 
phytoremediation of $\mathrm{Cd}$ in soils, but there is no data for water or how much time is required to perform the phytoremediation process.

This work evaluated the cadmium removal capacity of Echinochloa crusgalli L. at three different ages (20,30 and 45 days) to validate the duration of the phytoremediation by chemical analysis and ecotoxicological essays with both acute and chronic exposure by Daphnia similis as test-organism. Anatomical modifications will also be evaluated in the presence of the metal.

\section{MATERIAL AND METHODS}

The experiments were carried out in a greenhouse and E. crus-galli L. Beauv. seeds were used. Plants at 20,35 and 45 days after germination (DAG) were transferred to 2-L trays with modified Hoagland and Arnon 1950 nutritive solution (ionic force 40\%) supplemented with 0.8 $\mathrm{mg} \mathrm{L}^{-1}$ of $\mathrm{Cd}$ or, in the negative control, without $\mathrm{Cd}$ and incubated for 10 days. During this period, plants were sorted by size and shape to keep the population uniform as the test organism. Figure 1 shows a general design of the methodology used.

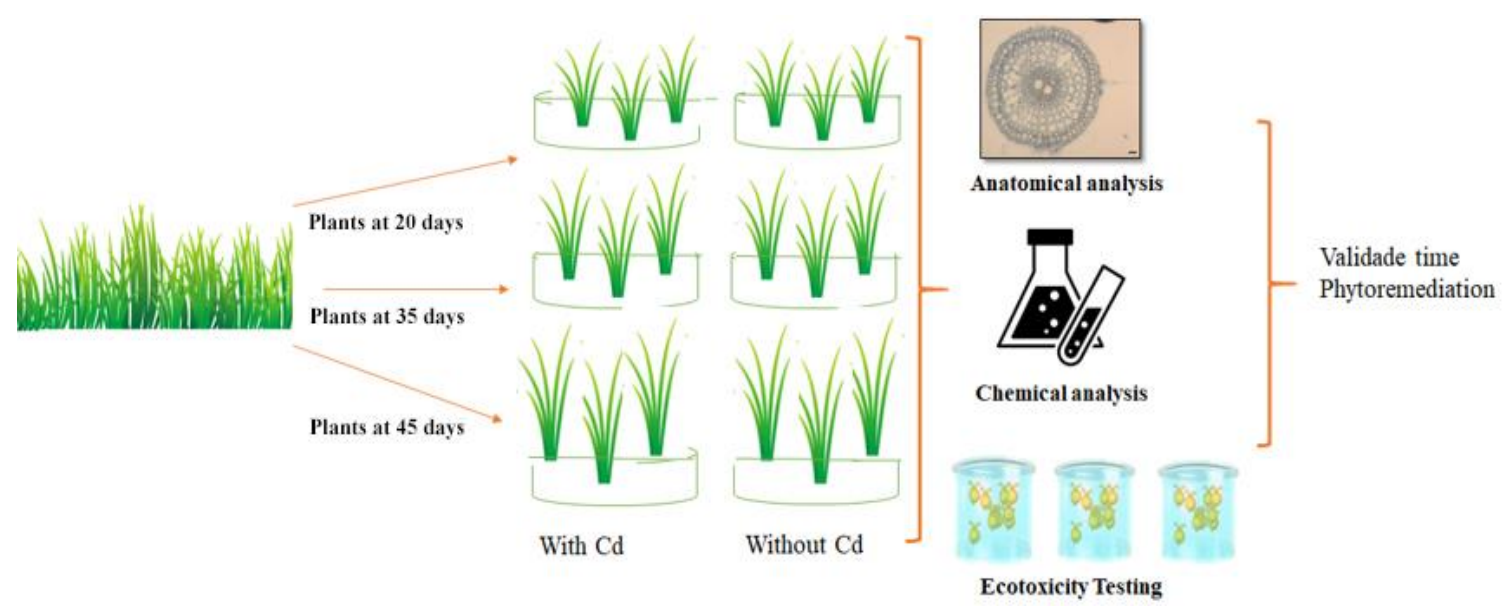

Figure 1. Design of the methodology using E. crus-galli L. Beauv.

The cadmium concentration used here $\left(0.8 \mathrm{mg} \mathrm{L}^{-1}\right)$ was four times higher than the maximum allowed according to Brazilian legislation CONAMA No. 430/2011 (Conama, 2011) for discharges in water bodies and nearly the maximum tolerated by E. crus-galli L. Beauv (unpublished data).

The experimental design was completely randomized (CRD) with $2 \times 3$ factorial (2 concentrations x 3 Days After Germination - DAG) and four replicates. Each replicate contained 15 plants. Initially, the normality of data was tested using Shapiro Wilk normality test $(p>0.05)$. In cases of non-normal data, the $(x+1) 0.5$ transformation were applied. After this, variance analyses were performed using the F test $(\mathrm{p}<0.05)$ and the Scott-Knott test was implemented in SISVAR software (Ferreira 2011).

To evaluate the capacity of Echinochloa crusgalli L. in removing cadmium at three different DAG, after 10 days of exposure the plants were removed and root samples were selected for anatomy analyses. Their roots were collected and fixed in FAA (formaldehyde, acetic acid and $70 \%$ alcohol) and later conserved in alcohol $70^{\circ} \mathrm{GL}$. They were cross-sectioned with manual microtome. The sections were stained with a $0.5 \%$ toluidine blue mixture, following methods described by Kraus and Arduin (1997). The sections were placed on slides with glycerinated gelatin and covered with coverslips. Three sections of blade were analyzed, one blade was mounted for each experimental replicate, and three measurements per section. The sessions were photomicrographed using an Olympus U-TV1X-2 digital camera coupled to the Olympus CX41 microscope and assisted by Carl Zeiss AxioVision Viewer 4.8 software. 
Measurements were performed without software for image analysis.

For each root section, an endoderm index, a count and a sequence of metaxylem calculations, and the Carlquist-IVC Vulnerability Index calculation (Carlquist, 1975) were measured according to Equation 1:

IVC $=$ Tracheal Element Diameter $(\mu \mathrm{M}) /$ Number of Tracheal Elements

The remainder, aerial parts and root system were separated for oven drying at $60^{\circ} \mathrm{C}$ for 72 hours. For Cd quantification (in $\mu \mathrm{g} \mathrm{g}^{-1}$ ), about $0.5 \mathrm{~g}$ of dry material was digested in $10 \mathrm{~mL}$ of $\mathrm{HNO}_{3}$, filtered in a rapid-flow quantitative filter and washed with $10 \mathrm{~mL}$ of MILLI Q water, according to USEPA (1998). The Cd accumulation and concentration in roots and in aerial parts were evaluated according to Equations 2 and 3:

Aerial part $=\mathrm{Cd}$ content in aerial part $\mathrm{x}$ dry - matter weight

Roots $=$ Cd content in roots $\mathrm{x}$ dry - matter weight

Quantification of $\mathrm{Cd}$ in plants and in the aqueous solutions after phytoremediation in the three phases of development and in the control were performed by flame atomic absorption spectrometry (Agilent Technologies 200 Series).

The Phytoremediation Index (PI) can be understood as the plant's ability to remove a certain amount of toxic element over time. This index is dependent on the relative growth rate (TCR), which represents the dry masses in grams $(\mathrm{g})$, the time in days and biomass accumulation of $\mathrm{Cd}$ in milligrams ( $\mathrm{mg}$ ) divided by the amount of dry mass of the plant in grams (g) for each age and proportional to the exposure time, according to Equation 4 (Pereira, 2010):

$\mathrm{PI}=(\mathrm{TCR} \times$ metal concentration $)$

To determine how many days plants should be kept in the system so that phytoremediation could reach the desired levels, Equation 5 was used - Phytoremediation in Days (PD).

$\mathrm{PD}=$ (Concentration / PI) / Plant's number

An acute and chronic bioassay was performed with the microcrustacean Daphnia similis Claus (Cladocera, Crustacea) according to Brazilian law Nbr 12713/2016 and Nbr 13.373/2017 (ABNT 2016; 2017). The test consisted of the exposure of 10 females of $D$. similis to the nutrient solution with and without $\mathrm{Cd}$ after phytoremediation with $E$. crus-galli L. within the 3 stages of growth: 20, 35 and 45 days after germination (DAG). As control 1, water was used to culture these organisms. The dead / living organisms were counted after $24 \mathrm{~h}$ to $120 \mathrm{~h}$ of exposure in the acute bioassay and for 10 days in the chronic bioassay. The following variables were quantified: Temperature $\left(\mathrm{T}^{\circ} \mathrm{C}\right)$, Conductivity $\left(\mu \mathrm{S} . \mathrm{cm}^{-1}\right)$, Dissolved Oxygen $\left(\mathrm{mg} \mathrm{L}^{-1}\right)$ and $\mathrm{pH}$ at the beginning and end of tests.

\section{RESULTS AND DISCUSSION}

\subsection{Anatomical analysis}

$\mathrm{Cd}$ and other heavy metals removal through phytoremediation emerges as a sustainable technology for contaminated wastewater (Mahajan and Kausha, 2018). In this experiment, no association was observed between the ages of E. crus-galli and Cd concentration in different anatomical parameters. These variables behaved independently the presence of $\mathrm{Cd}$, as in Table 1: 
Table 1. Percentage of aerenchyma in cortex, Carlquist vulnerability index (CVI) and endoderm thickness $(\mu \mathrm{m})$ of Echinochloa crusgalli roots in relation to DAG.

\begin{tabular}{cccc}
\hline Time DAG & Aerenchyma $(\%)$ & CVI & Endoderm thickness $(\mu \mathrm{m})$ \\
\hline 20 & $24.8 \mathrm{a}$ & $14.1 \mathrm{a}$ & $10.7 \mathrm{~b}$ \\
35 & $14.4 \mathrm{~b}$ & $9.6 \mathrm{a}$ & $12.2 \mathrm{a}$ \\
45 & $8.4 \mathrm{~b}$ & $17.6 \mathrm{a}$ & $12.2 \mathrm{a}$ \\
\hline $\mathrm{CV}(\%)$ & 48 & 51 & 7.35 \\
\hline * Averages followed by the same letter do not differ statistically from \\
each other (Skott-knott, 5\%).
\end{tabular}

E. crus-galli is considered a weed to several crops from flooded and/or irrigated areas, particularly rice crops. As a strategy for anaerobic conditions, rice developed aerenchyma, which allows the transport of $\mathrm{O}_{2}$ from the air to the roots. Aerenchyma formation can be constitutive or induced by an environmental factor (Castro et al., 2009). In the present study, there was higher aerenchyma formation in roots of plants at $20 \mathrm{DAG}$, which might be associated with a strategy for establishment in a flooded environment (as the trays used in our assays). The same occurred at a lower intensity in older plants (Table 1). Starting at 35 DAG, there was a lower number of aerenchyma, which may favor the adaptation of these plants to environments contaminated with heavy metals, since with more cells, more Cd probably could fixate within their walls (Tian et al., 2011; Küpper and Andresen, 2016). The result of CVI of E. crus-galli plants for all ages analyzed indicate that the transport of assimilates and nutrients were not affected by the presence of $\mathrm{Cd}$ in the solution.

Plants cannot escape fluctuations in nutrient availability and / or toxicity in their environment, so they create endodermal barriers. They are modified in response to a multitude of abiotic stresses (Doblas et al., 2017). Endoderm thickening, as observed in Table 1, may have protective roles for the root system because of lignin impregnation within the cell walls. These barriers can be formed when roots are exposed to high concentrations of potentially toxic elements such as Cd (Lux et al., 2011). According to Silva et al., (2013) and Castro et al., (2009), apoplastic barriers can act as biological filters, avoiding the excessive absorption of $\mathrm{Cd}$ following the obligatory symplast path, which reduces metal translocation to the aerial part, thus protecting the photosynthetic system from its toxic effects. The plant's root is the organ in charge of nutrient acquisition, but at the same time it must provide an efficient boundary against external stresses in order to maintain plant fitness.

\subsection{Chemical analysis}

The results of the present study indicated that the cadmium in plants showed higher concentration and accumulation in roots than in the aerial parts during 10 days of exposure for all plant ages (20, 30 and 45 DAG) (Table 2). 
Table 2. Cd concentration and accumulation in root and aerial part of Echinochloa crus-galli L. grown in solution with Cd and phytoremediation in days. Phytorem: Phytoremediation.

\begin{tabular}{|c|c|c|c|c|c|c|c|c|}
\hline $\begin{array}{l}\text { Time } \\
\text { DAG }\end{array}$ & $\begin{array}{c}{[\mathrm{Cd}]} \\
\left(\mathrm{mg} \mathrm{L}^{-1}\right)\end{array}$ & $\begin{array}{l}\text { Weight of root } \\
\text { dry mass }(g)\end{array}$ & $\begin{array}{l}{[\mathrm{Cd}] \text { in root }} \\
\quad(\mu \mathrm{g} g)\end{array}$ & $\begin{array}{l}\text { Cd Accumulation in } \\
\operatorname{root}(\mu \mathrm{gg})\end{array}$ & $\begin{array}{l}\text { Weight of aerial part } \\
\text { dry mass }(\mathrm{g})\end{array}$ & $\begin{array}{c}{[\mathrm{Cd}] \text { in aerial }} \\
\text { part }(\mu \mathrm{g} g)\end{array}$ & $\begin{array}{c}\mathrm{Cd} \\
\text { accumulation in } \\
\text { aerial part } \\
(\mu \mathrm{g} \mathrm{g})\end{array}$ & $\begin{array}{l}\text { Phytorem. in days } \\
\text { (PD) }\end{array}$ \\
\hline 20 & 0 & $0,413 \pm 0,04 \mathrm{~b}$ & $3,3 \pm 0,3 \mathrm{~d}$ & $0,01 \pm 0,003 \mathrm{~d}$ & $0,520 \pm 0,04 \mathrm{c}$ & $2,3 \pm 1,7 \mathrm{c}$ & $0,01 \pm 0,001 \mathrm{~d}$ & 0 \\
\hline 35 & 0 & $0,416 \pm 0,04 \mathrm{~b}$ & $6,2 \pm 0,3 \mathrm{~d}$ & $0,02 \pm 0,003 \mathrm{~d}$ & $0,850 \pm 0,04 \mathrm{~b}$ & $3,1 \pm 1,7 \mathrm{c}$ & $0,02 \pm 0,001 \mathrm{~d}$ & 0 \\
\hline 45 & 0 & $0,503 \pm 0,04 \mathrm{~b}$ & $6,4 \pm 0,3 \mathrm{~d}$ & $0,03 \pm 0,003 \mathrm{~d}$ & $0,916 \pm 0,04 \mathrm{a}$ & $5,4 \pm 1,7 \mathrm{c}$ & $0,04 \pm 0,001 \mathrm{~d}$ & 0 \\
\hline 20 & 0,8 & $0,346 \pm 0,04 \mathrm{~b}$ & $313,7 \pm 9,1 \mathrm{a}$ & $0,55 \pm 0,03 \mathrm{c}$ & $0,516 \pm 0,04 \mathrm{c}$ & $51,7 \pm 1,7 \mathrm{a}$ & $0,27 \pm 0,01 \mathrm{c}$ & $19 \pm 1 \mathrm{a}$ \\
\hline 35 & 0,8 & $0,466 \pm 0,04 \mathrm{~b}$ & $270,3 \pm 9,1 \mathrm{~b}$ & $0,83 \pm 0,03 \mathrm{~b}$ & $0,796 \pm 0,04 \mathrm{~b}$ & $38,9 \pm 1,7 \mathrm{~b}$ & $0,35 \pm 0,01 \mathrm{~b}$ & $16 \pm 1 \mathrm{a}$ \\
\hline 45 & 0,8 & $0,896 \pm 0,04 \mathrm{a}$ & $231,7 \pm 9,1 \mathrm{c}$ & $1,36 \pm 0,03 \mathrm{a}$ & $0,906 \pm 0,04 \mathrm{a}$ & $54,0 \pm 1,7 \mathrm{a}$ & $0,40 \pm 0,01 \mathrm{a}$ & $16 \pm 1 \mathrm{a}$ \\
\hline
\end{tabular}

* Averages followed by the same letter in the column do not differ statistically from each other (Skott-knott, 5\%). Transformed data. 
Plants at 45 days when grown in cadmium solution presented higher weight of dry root matter compared to plants without metal solution. This result demonstrates the tolerance of these plants at low concentrations of Cd. Ezaki et al. (2008) also observed that at concentrations below $0.1 \mathrm{mM}$ of $\mathrm{Cd}$ and $\mathrm{Cu}$, Echinochloa crus-galli showed tolerance, not changing the relative length of the roots. The higher dry-mass weight of the 45-day $\mathrm{Cd}$ treatment contributed to the higher accumulation of $\mathrm{Cd}$ in the root. The weight of aerial part dry mass increased over time, contributing to the accumulation of $\mathrm{Cd}$ in aerial parts over time. This root accumulation can also be explained by endoderm thickness on the 35- to 45-day-old plants which act as apoplastic barriers in the roots protecting the aerial part. Similar results were also observed by De Maria et al., (2013) with sunflowers, concluding that in the initial growth phase, the first most probable response of the plant was metal accumulation (with the production of phytochelatins that immobilize $\mathrm{Cd}$ in cells), whereas later, plants reduce and/or block the absorption and translocation of the toxic metal. Lux et al., (2011) confirmed that cadmium-concentrations are often higher in roots than in aerial parts. Regarding time, Gomes et al., (2014) observed that efficiency in reducing mercury $(\mathrm{Hg})$ using young Typha domingensis $(10 \mathrm{~cm}$ of the water column) is dependent on the time of exposure. The authors found that at less than 5 days, $90 \%$ of $\mathrm{Hg}$ had been removed from the water column. This result can be explained by the biomass difference between $T$. domingensis and E. crus-galli macrophytes. It was observed that at all ages of E. crus-galli, there was $25 \%$ absorption, which indicates inadequate exposure time, since it did not reach the maximum limit allowed for the release of effluent by Brazilian Legislation $\left(0.2 \mathrm{mg} \mathrm{L}^{-1}\right.$ of $\left.\mathrm{Cd}\right)$. This fact may be due to the occurrence of saturation of the binding sites of this metal in E. crus-galli roots (Table 2). This same result was found by Oliveira et al., (2001) when exposing Eichhornia crassipes to solution with different $\mathrm{Cd}$ concentrations. The authors observed that above $1 \mathrm{~g} \mathrm{~L}^{-1}$, saturation of the binding sites of this metal in the roots plants was observed, since the increase in the Cd content in roots was only $7.3 \%$, even with a two-fold increase in the concentration of this element in the nutrient solution. Bindu et al., (2010) evaluated the phytoremediation capacity of Colocasia esculenta at different $\mathrm{Cd}$ concentrations and observed that at the same concentration over time there was an increase in the $\mathrm{Cd}$ removal percentage. Plants were evaluated at 5, 10, 15 and 20 days of exposure, obtaining $30.5 \%, 34.5 \%, 40.5 \%$ and $41 \%$ of removal, respectively, at a Cd concentration of 2 $\mathrm{mg} \mathrm{L}^{-1}$. In the present study, since $E$. crus-galli $L$ had smaller biomass compared to C. esculenta and no rhizome, the presented removal percentage was around $25 \%$ at 10 days of exposure.

The calculation in phytoremediation days was performed because of the lack of this information in the literature. This information is useful for companies that wish to employ phytoremediation as an alternative to remove $\mathrm{Cd}$ from their contaminated wastewaters. It was found that values between 16 and 19 days (estimated by Phytoremediation in Days (PD), regardless of plant age, would be sufficient time for remediation of the solution containing $\mathrm{Cd}$ at the test concentration (Table 1). E. crus-galli L. has potential for Cd phytoremediation at low concentrations of $\mathrm{Cd}$ in solution; however, in our experiment, $\mathrm{Cd}$ concentrations in the solution remained higher than that allowed by Brazilian law. It is possible to conclude that E. crus-galli L with higher biomass, that is, with greater DAG, would be more likely to survive for 16 to 19 days, tolerating the phytotoxicity of this metal (Table 1). According to Fernandes (2014), at Cd concentrations of up to $1 \mathrm{mg} \mathrm{L}^{-1}$ in solution, this plant did not present morphological and physiological damage (non-published data). However, in order to achieve this result, it is necessary to increase root biomass, which is responsible for assimilation.

Within the analyzed the ages of E. crusgalli (20,35 or 45 DAG), the exposure time of 10 days was not sufficient to verify differences in the cadmium removal from the solution. For DAG times of 20, 35 and 45, Cd concentration in the solution $\left(\mathrm{mg} \mathrm{L}^{-1}\right)$ was $0.60 \pm 0.02 ; 0.57$ $\pm 0.02 ; 0.63 \pm 0.02$, respectively. The control was $0.09 \pm 0.02 \mathrm{mg} \mathrm{L}^{-1}$. 


\subsection{Ecotoxicity testing}

In relation to the ecotoxicological assays, no acute effect after 48 hours of exposure of $D$. similis was observed in the solution after phytoremediation. However, at this residual concentration ( $0.6 \mathrm{mg} \mathrm{L}^{-1}$ of $\mathrm{Cd}$ ), exposed for longer time (10 days), chronic effects were observed (Figure 2). Although the addition of the nutrient solution has caused a considerable increase in the conductivity values, this alteration was not enough to provoke an osmotic imbalance in D. similis, but the effect observed was due to the presence of residual cadmium.

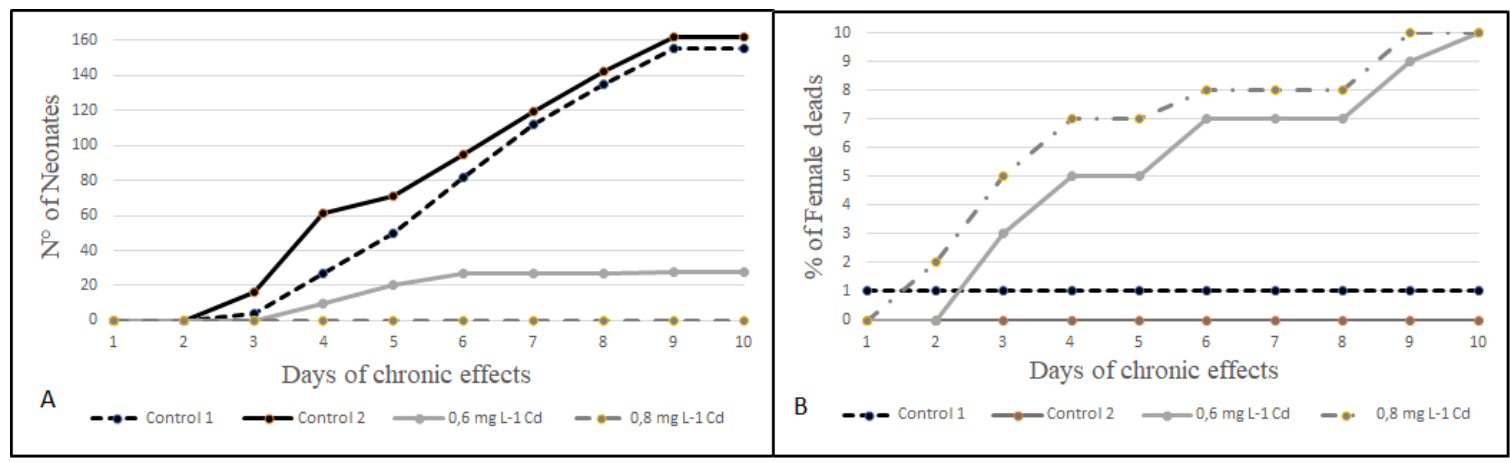

Figure 2. Results of ecotoxicological assays. Daphnia similis survival at different exposure times in solution with and without $\mathrm{Cd}$ after phytoremediation with Echinochloa crusgalli L. for 10 days. Legend: Control 1 - Cultivation water; Control 2 - Hoagland and Arnon nutritive solution (1950) without $\mathrm{Cd}$; [0.6 mg L ${ }^{-1} \mathrm{Cd}$ ] - Nutritive Solution with $\mathrm{Cd}$ after 10 days (Onset); [0.8 $\mathrm{mg} \mathrm{L}^{-1} \mathrm{Cd}$ ] Hoagland and Arnon Nutritive Solution (1950) with Cd (Ending).

For females of $D$. similis exposed for 10 days at $0.6 \mathrm{mg} \mathrm{L}^{-1} \mathrm{Cd}$ concentration (after phytoremediation), there was an effect on reproduction, with low production of newborns and non-reproduction in those exposed to $0.8 \mathrm{mg} \mathrm{L}^{-1} \mathrm{Cd}$ (initial concentration) (Figure 2a). These results are corroborated by the low survival rate of females (Figure $2 b$ ). Phytoremediation using E. crus-galli reduced the toxicity by only $25 \%$. Penha et al. (2014) observed similar data when exposing Girarda sp. to $0.8 \mathrm{mg} \mathrm{L}^{-1} \mathrm{CdSO}_{4}$ for 96 hours, with only $35 \%$ survival. The results of ecotoxicological tests corroborate those obtained in the present study, in which this effluent cannot be released into aquatic ecosystem according to Brazilian Resolution 430/2011, since toxicity has not been fully removed, remaining above the legal threshold.

\section{CONCLUSIONS}

Our data indicate that exposures of E. crus-galli for periods longer than 19 days may be required to reduce the concentrations of $\mathrm{Cd}$ in water to levels that comply with Brazilian legislation. Under these conditions, ecotoxicological tests were important tools for evaluation of the efficiency of the process. However, this kind of evaluation is not common to phytoremediation studies.

Independent of DAG, E. crus-galli reduces around or up to $25 \% \mathrm{Cd}$ toxicity in the contaminated solution. For this, this species can be used in phytoremediation programs of $\mathrm{Cd}$ with other plants.

As a characteristic of aquatic macrophytes, the species used adapts to different environmental conditions, a fact that was observed after root anatomy analysis.

\section{ACKNOWLEDGMENTS}

This work was supported by CNPq (National Counsel of Technological and Scientific Development) and CAPES (Coordination for the Improvement of Higher Education Personnel) 
for grants and financial support. Institute of Rice Yield of Rio Grande do Sul is greatly thanked for the donation of $E$. crusgalli seeds.

\section{REFERENCES}

ANDRADE, J. C. M.; TAVARES, S. R. L.; MAHLER, C. F. Fitorremediação: o uso de plantas na melhoria da qualidade ambiental. São Paulo: Oficina de textos, 2007. 176 p.

ABNT. NBR 12713: Ecotoxicologia aquática: toxicidade aguda: método de ensaio com Daphnia spp (Crustacea, Cladocera). Rio de Janeiro, 2016.

ABNT. NBR 13373: Ecotoxicologia aquática - Toxicidade crônica - Método de ensaio com Ceriodaphnia spp (Crustacea, Cladocera). Rio de Janeiro, 2017.

BINDU, T.; SUMI, M. M.; RAMASAMY, E. V. Decontamination of water polluted by heavy metals with Taro (Colocasia esculenta) cultured in a hydroponic NFT system. Environmentalist, v. 30, n. 1, p. 35-44, 2010. https://doi.org/10.1007/s10669-009-92406

CARLQUIST, S. Ecological strategies of xylem evolution. California: University of California, 1975. $259 \mathrm{p}$.

CASTRO, E. M.; PEREIRA, F. J.; PAIVA, R. Histologia Vegetal: Estrutura e Função de Órgãos Vegetativos. Lavras: UFLA, 2009. 234 p.

CONAMA (Brasil). Resolução n 430 de 13 de maio 2011. Dispõe sobre as condições e padrões de lançamento de efluentes, complementa e altera a Resolução no 357, de 17 de março de 2005, do Conselho Nacional do Meio Ambiente-CONAMA. Diário Oficial [da] União: seção 1, Brasília, DF, n. 92, p. 89, 16 maio 2011.

COSTA, R. C.; OliVI, P.; BOTTA, C. M. R.; ESPINDOLA, E. L. G. A toxicidade em ambientes aquáticos: discussão e métodos de avaliação. Química Nova, v. 31, n. 7, p. 1820-1830, 2008.

DE MARIA, S.; PUSCHENREITER, M.; RIVELLI, A. R. Cadmium accumulation and physiological response of sunflower plants to $\mathrm{Cd}$ during the vegetative growing cycle. Plant, Soil and Environment, v. 59, n. 6, p. 254-261, 2013. https://doi.org/10.17221/788/2012-PSE

DE SOUZA, C. B.; SILVA, G. R. Phytoremediation of Effluents Contaminated with Heavy Metals by Floating Aquatic Macrophytes Species. In: JACOB-LOPES, E.; ZEPKA, L. Q. (Eds.). Biotechnology and Bioengineering. IntechOpen, 2019. https://dx.doi.org/10.5772/intechopen.83645

DOBLAS, V. G.; GELDNER, N.; BARBERON, M. The endodermis, a tightly controlled barrier for nutrients. Current Opinion in Plant Biology, v. 39, p. 136-143, 2017. https://dx.doi.org/10.1016/j.pbi.2017.06.010

EKWEOZOR, I. K. E.; UGBOMEH, A. P.; OGBUEHI, K. A. Zn, Pb, Cr and Cd concentrations in fish, water and sediment from the Azuabie Creek, Port Harcourt. Journal of Applied Science and Environment Management, v. 21, n. 1, p. 87-91, 2017. http://dx.doi.org/10.4314/jasem.v21i1.9 
EZAKI, B.; NAGAO, E.; YAMAMOTO, Y.; NAKASHIMA, S.; ENOMOTO, T. Wild plants, Andropogon virginicus L. and Miscanthus sinensis Anders, are tolerant to multiple stresses including aluminum, heavy metals and oxidative stresses. Plant cell reports, $v$. 27, n. 5, p. 951-961, 2008. https://doi.org/10.1007/s00299-007-0503-8

FAWZY, M. A.; BADR, N. E.; EL-KHATIB, A.; ABO-EL-KASSEM, A. Heavy metal biomonitoring and phytoremediation potentialities of aquatic macrophytes in River Nile. Environment Monitoring and Assessing, v. 184, n. 3, p. 1753-1771, 2012. https://doi.org/10.1007/s10661-011-2076-9

FERNANDES, K. D. Utilização de capim-arroz (Echinochloa crusgalli (L.) P. Beauv.) para fitorremediação de cádmio evidenciado pelo speckle laser dinâmico e modificações anatômicas e fisiológicas. 2014. 85 p. Tese (Doutorado em Botânica Aplicada) Universidade Federal de Lavras, Lavras, 2014.

FERREIRA, D. F. SISVAR: a computer statistical analysis system. Ciência e Agrotecnologia, v. 35, n. 6, p. 1039-1042, 2011. http://dx.doi.org/10.1590/S1413-70542011000600001

GOMES, H. I. Phytoremediation for bioenergy: challenges and opportunities. Environmental $\begin{array}{llllll}\text { Technology } & \text { Reviews, } & \text { v. } & 1, & \text { p. } & \text { 59-66, }\end{array}$ https://doi.org/10.1080/09593330.2012.696715

GOMES, M. V. T.; SOUZA, R. R.; TELES, V. S.; MENDES, E. A. Phytoremediation of water contaminated with mercury using Typha domingensis in constructed wetland. $\begin{array}{lllll}\text { Chemosphere, } & \text { v. } & 103, & \text { p. } & 228-233,\end{array}$ https://doi.org/10.1016/j.chemosphere.2013.11.071

KO, K.; LEE, P.; KONG, I. C. Evaluation of the toxic effects of arsenite, chromate, cadmium, and copper using a battery of four bioassays. Applied Microbiology and Biotechnology, v. 95, n. 5, p. 1343-1350, 2012. https://dx.doi.org/10.1007/s00253-011-3724-2

KRAUS, J. E.; ARDUIN, M. Manual básico de métodos em morfologia vegetal. Seropédica: Editora da Universidade Rural, 1997. 198 p.

KÜPPER, H.; ANDRESEN, E. Mechanisms of metal toxicity in plants. Metallomics, v. 8, n. 3, p. 269-285, 2016. https://dx.doi.org/10.1039/C5MT00244C

LUX, A.; MARTINKA, M.; VACULIK, M.; WHITE, P. J. Root responses to cadmium in the rhizosphere: a review. Journal of Experimental Botany, v. 62, n. 1, p. 21-37, 2011. https://dx.doi.org/10.1093/jxb/erq281 .

MAHAJAN, P.; KAUSHAL, J. Role of Phytoremediation in Reducing Cadmium Toxicity in Soil and Water. Journal of Toxicology, v. 2018, 2018. https://dx.doi.org/10.1155/2018/4864365

MARTELO, J.; LARA BORRERO, J. A. Macrófitas flotantes en el tratamiento de aguas residuales: una revisión del estado del arte. Ingeniería y ciencia, v. 8, n. 15, p. 221-243, 2012.

OLIVEIRA, J. A.; CAMBRAIA, J.; CANO, M. A. O.; JORDÃO, C. P. Absorção e acúmulo de cádmio e seus efeitos sobre o crescimento relativo de plantas de aguapé e de salvínia. Revista Brasileira de Fisiologia Vegetal, v. 13, n. 3, 2001. http://dx.doi.org/10.1590/S0103-31312001000300008 
PENG, Q.; CHEN, W.; WU, L.; BAI, L. The Uptake, Accumulation, and Toxic Effects of Cadmium in Barnyardgrass (Echinochloa crus-galli). Polish Journal of Environmental Studies, v. 26, n. 2, p. 779-784, 2017. https://dx.doi.org/10.15244/pjoes/65780

PENHA, B. R.; CARVALHO, R. D. S.; MORAIS, F. V.; LOPES, K. A. R.; VELHO, N. M. R. C. Avaliação dos efeitos da toxicidade em planárias límnicas expostas a cádmio e cromo. Revista Biociências, v. 20, n. 2, p. 13-21, 2014.

PEREIRA, F. J.; CASTRO, E. M.; OLIVEIRA, C. P.; PASQUAL, M. Mecanismos anatômicos e fisiológicos de planta de aguapé para a tolerância à contaminação por Arsênio. Planta Daninha, v. 29, n. 2, 2011. http://dx.doi.org/10.1590/s0100-83582011000200003

PEREIRA, F. J. Características anatômicas e fisiológicas de aguapé e Índice de fitorremediação de alface d'agua cultivados na presença de arsênio, cádmio e chumbo. 2010. Thesis (Doctorate in Agronomy / Plant Physiology) - University of Lavras, Lavras, 2010.

QIU, Y.W.; WANG, W. X. Comparison of mercury bioaccumulation between wild and mariculture food chains from a subtropical bay of Southern China. Environmental geochemistry and health, v. 38, n. 1, p. 39-49, 2016. https://doi.org/10.1007/s10653015-9677-0

SILVA, A. S.; TECHIO, V. H.; CASTRO, E. M.; FARIA, M. R.; PALMIERI, M. J. Reproductive, cellular, and anatomical alterations in Pistia stratiotes L. plants exposed to cadmium. Water, Air, \& Soil Pollution, v. 224, p. 1465-1477, 2013. https://doi.org/10.1007/s11270-013-1454-z

SINGHA, K. T.; SEBASTIAN, A.; PRASAD, M. N. V. Iron plaque formation in the roots of Pistia stratiotes L.: importance in phytoremediation of cadmium. International journal $\begin{array}{lllllll}\text { of phytoremediation, } & \text { v. } 21, \quad \text { n. } & 2, & \text { p. } & 120-128,\end{array}$ https://doi.org/10.1080/15226514.2018.1474442

SHARMA, P.; PANDEY, S. Status of phytoremediation in world scenario. International Journal of Environmental Bioremediation \& Biodegradation, v. 2, p. 178-191, 2014. https://dx.doi.org/10.12691/ijebb-2-4-5

SHOVON, M. N. H.; MAJUMDAR, B. C.; RAHMAN, Z. Heavy metals (Lead, Cadmium and Nickel) concentration in different organs of three commonly consumed fishes in Bangladesh. Fisheries and Aquaculture Journal, v. 8, n. 3, p. 1-6, 2017.

TIAN, S.; LU, L.; LABAVITCH, J.; YANG, X.; HE, Z.; HU, H.; BROWN, P. Cellular sequestration of cadmium in the hyperaccumulator plant species Sedum alfredii. Plant Physiology, v. 157, n. 4, p. 1914-1925, 2011. https://doi.org/10.1104/pp.111.183947

ULLAH, A.; HENG, S.; MUNIS, M. F. H.; FAHAD, S.; YANG, X. Phytoremediation of heavy metals assisted by plant growth promoting (PGP) bacteria: A review. Environ Exper Bot 117: 28-40, 2015. https://doi.org/10.1016/j.envexpbot.2015.05.001

USEPA. Method 3051 A: microwave assisted acid digestion of sediments, sludge, soils and oils. Washington, 1998. 